\title{
Uptake and bioaccumulation of PCDD/Fs in earthworms after in situ and in vitro exposure to soil from a contaminated sawmill site
}

\author{
S. Henriksson ${ }^{\text {a,b,* }}$, F. Bjurlid ${ }^{\text {b }}$, A. Rotander ${ }^{\text {b }}$, M. Engwall ${ }^{\text {b }}$, G. Lindström ${ }^{\text {b }}$, H. Westberg ${ }^{\text {b,c }}$, J. Hagberg ${ }^{\text {b,c }}$ \\ a 15 Environmental Staff, SE-671 81 Arvika, Sweden \\ ${ }^{\mathrm{b}}$ MTM Research Centre, Örebro University, SE-701 82 Örebro, Sweden \\ c Department of Occupational and Environmental Medicine, Faculty of Medicine and Health, Örebro University, SE-70182 Örebro, Sweden
}

\section{H I G H L I G H T S}

- PCDD/Fs concentrations in earthworms show transfer from contaminated soil to biota.

- Bioaccumulation factors for in situ and in vitro $\mathrm{PCDD} / \mathrm{Fs}$ exposed earthworms.

- Risk assessments of contaminated sites should contain bioavailability information.

\section{G R A P H I C A L A B S T R A C T}

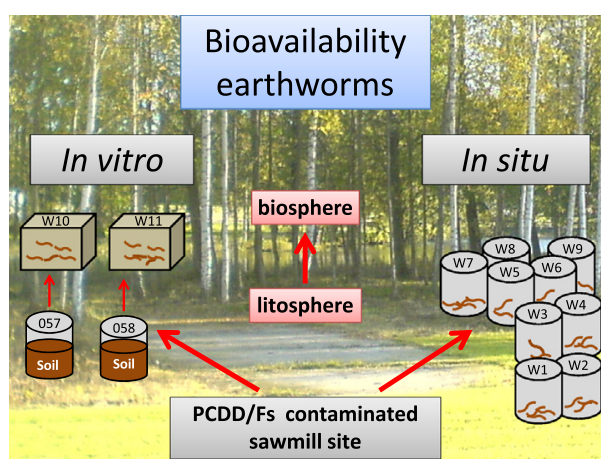

\begin{abstract}
A B S T R A C T
Uptake of polychlorinated dibenzo-p-dioxins and polychlorinated dibenzofurans (PCDD/Fs) was studied in earthworms collected from a sawmill site in Sweden with severe PCDD/Fs contamination (the hot spot concentration was 690,000 ng TEQ ${ }_{\text {WHO2005 }} / \mathrm{kg}$ d.w.) in order to investigate the transfer of PCDD/Fs from the site to the biota. PCDD/Fs concentrations in the collected earthworms were compared to PCDD/Fs concentrations in laboratory exposed earthworms (Eisenia fetida), which were exposed to contaminated soils from the sawmill site for 34 days. All analyses were performed by high resolution gas chromatography/high resolution mass spectrometry (HRGC/HRMS). PCDD/Fs concentrations in the earthworms ranged from 290 to $520,000 \mathrm{pg} / \mathrm{g}$ (f.w.). The main congeners found in both soils and earthworms were OCDF, 1234678-HpCDF, OCDD and 1234678-HpCDD. The study showed that the PCDD/Fs in the soil were biovailable to the earthworms and the PCDD/Fs concentrations in the soils correlated with the concentrations in the earthworms. Earthworm samples from soil with lower concentration had higher bioaccumulation factors than samples from soils with high concentration of contamination. Thus, a less contaminated soil could yield higher concentrations in earthworms compared to a higher contaminated soil. Assuming that when assessing risks with PCDD/F contaminated soil, a combination of chemical analysis of soil PCDD/Fs concentrations and bioavailability should be employed for a more comprehensive risk assessment.
\end{abstract}

(c) 2016 Published by Elsevier B.V.

\footnotetext{
* Corresponding author at: MTM Research Centre, Örebro University, SE-701 82 Örebro, Sweden.

E-mail address: sara.henriksson@arvika.se (S. Henriksson).
} 


\section{Introduction}

Hillringsberg is one of the most heavily polluted sawmill sites in Sweden. The sawmill site has been contaminated for decades by spills of Dowicide G, the sodium pentachlorophenate (NaPCP) preservative from Dow Sweden Ltd. (Persson et al., 2007; Länsstyrelsen Värmland, 2010; Henriksson et al., 2013). Dowicide G and other chlorophenolbased preservatives contained polychlorinated dibenzo- $p$-dioxins and polychlorinated dibenzofurans (PCDD/Fs), unintentionally formed during their fabrication (Rappe and Garå, 1978, Hagenmaier and Brunner, 1987, Masunaga et al., 2001). An earlier study showed that a soil sample from the preservation area had a PCDD/Fs concentration of 690,000 ng $\mathrm{TEQ}_{\text {WHO2005 }} / \mathrm{kg}$ d.w. (Henriksson et al., 2013). The level is 3450 times higher than the Swedish generic guideline value $\left(200 \mathrm{ng} \mathrm{TEQ}_{\mathrm{wHO}} \mathrm{mo05} / \mathrm{kg}\right.$ d.w.) for industrial land use and 34,500 times higher than the Swedish generic guideline value $\left(20 \mathrm{ng} \mathrm{TEQ}_{\mathrm{WHO} 2005} / \mathrm{kg} \mathrm{d}\right.$.w.) for habitation land (SEPA/SNV, 2009). The main PCDD/Fs congeners at the site were OCDD, 1,2,3,4,6,7,8-HpCDD, OCDF and 1,2,3,4,6,7,8-HpCDF which reflects the main contaminants in Dowicide G (Persson et al., 2007; Länsstyrelsen Värmland, 2010; Henriksson et al., 2013). Since soils are heterogeneous environmental matrices with varying spatial and temporal distribution of organic carbon, $\mathrm{pH}$, humidity, particle size distribution, the measured PCDD/Fs concentration in the soil is not the same as the environmentally bioavailable concentration, which is also dependent on the duration of contact between compound and soil (aging) and physicochemical properties of the compounds. Therefore knowledge of the site specific uptake and bioaccumulation is necessary for adequate assessment of environmental and human health risks associated with a contaminated site (Belfroid et al., 1995; Matscheko et al., 2002a, 2002b; Lanno et al., 2004). A good supplement to chemical analysis of soil in a site specific risk assessment is investigation of the amount of PCDD/Fs which are bioavailable to earthworms. Earthworms are suitable organisms when assessing bioavailability since they can be found in a variety of soil types, including contaminated soils and are more or less in constant contact with the soil which makes them highly exposed to soil bound substances, through either direct dermal contact or ingestion of soil or specific fractions of the soil (Lanno et al., 2004). Earthworms can have a strong influence on the bioavailability of PCDD/Fs to other organisms by serving as prey to birds or other predators. Thus earthworms represent a potential transfer route from soil into the food web. In addition, their limited mobility (2.5-14 $\mathrm{m} \mathrm{yr}^{-1}$ ) (Emmerling and Strunk, 2012) makes them an appropriate species for monitoring the potential impact of local organic contaminants in soil, (Reinecke and Nash, 1984; Kitunen et al., 1987; Knuutinen et al., 1990; Laine et al., 1995; Matscheko et al., 2002a, 2002b; Jager et al., 2005).

Although, the bioavailability and contamination patterns are important in pollutant fate risk assessments of contaminated sites information of the site specific bioavailability of the pollutants generated from field studies are often missing.

The aim of this study was to investigate the uptake of PCDD/Fs in earthworms at a former sawmill site and evaluate if earthworms represent a potential transfer route from soil into the food web. Concentrations of $\mathrm{PCDD} / \mathrm{Fs}$ in earthworms found at the site (in situ) were compared to $\mathrm{PCDD} / \mathrm{Fs}$ concentrations in laboratory exposed earthworms (in vitro). Furthermore, bioaccumulation factors (BAFs) were calculated to provide site specific bioavailability assessment of each PCDD/Fs congener beyond the factual PCDD/Fs concentrations.

The results will be useful in the risk assessments of the site and can be helpful in risk assessments of other PCDD/Fs contaminated sites.

\section{Material and methods}

The uptake of PCDD/Fs into earthworms was studied by two different experiments; in situ and in vitro. In the in situ experiment PCDD/Fs concentrations were determined in earthworms collected from the contaminated sawmill site. In the in vitro experiment the PCDD/Fs concentrations were determined in earthworms (Eisenia fetida) exposed in the laboratory to contaminated soil collected from the same sawmill site. The earthworm species Eisenia fetida is available commercially and is recommended by the Organisation for Economic Co-operation and Development (OECD) for tests of acute and subacute toxicity of soil associated pollutants (OECD, 1984).

The site is divided into four subareas due to the former sawmill activities: the preservation area (PA), the landfill area (LF), the storage area (SA) and the remaining area (RA). The subareas are printed over an aerial photo of the site from 1961 (Fig. 1). The same figure shows the sampling points of soil and earthworms. Sampling points where both soil and earthworms were collected are marked with a yellow circle and are presented in this article. More information of the other sampling points and spatial distribution of the PCDD/Fs contamination is found in a former article (Henriksson et al., 2013).

\subsection{In situ experiment - earthworms collected from the sawmill site}

Earthworms were collected from sampling points 018, 057, 058, 027 and BP056 (Fig. 1) in June 2007 and 2008 by hand sorting using a stainless steel spade (depth $<20 \mathrm{~cm}$ ). The sampling points were coordinate determined and already named and used during environmental investigations to estimate the degree of PCDD/Fs contamination in the soil (Henriksson et al., 2013). All species of earthworms, mainly Aporrectodea caliginosa and Lumbricus rubellus (J. Lagerlöf, Swedish University of Agricultural Sciences, personal communication), which were found at the same sampling point and sampling time were collected and pooled as one sample. This resulted in nine earthworm samples (W1-W9) whereof eight of these were pools consisting of 2-6 earthworms. Sample W6 consisted of one earthworm only because earthworms were scarce at the sampling point 018 as a result of the high concentration of contaminants. Sample W6 is not as representative as the other pools but provides interesting information to the study as it comes from the hot spot of the site. The earthworms were transferred to the laboratory in glass jars filled in their native soils. Two earthworm pools (W1 and W2) were collected from the SA subarea; W1 from sampling point 027 and W2 from sampling point BP056 (Fig. 1). The seven remaining earthworm pools (W3-W9) were collected from the PA subarea at various times during June 2007 and 2008. W4 and W7 were collected from sampling point 058 . W6 were collected from the sampling point 018 which is the hot spot of the site and W3, W5, W8 and W9 were collected from sampling point 057 (Fig. 1). Prior to analysis the earthworm pools were treated according to Jager et al. (Jager et al., 2005). First the earthworms were rinsed in distilled water. Thereafter were they kept on moist filter paper in Petri dishes for $48 \mathrm{~h}$ to allow them to clear their gut. Distilled water was added to each container to provide sufficient moisture content. Filter paper was changed after $24 \mathrm{~h}$. After depuration, the earthworms were once again rinsed in distilled water and then packed in aluminum foil and put in a freezer $\left(-20{ }^{\circ} \mathrm{C}\right)$, where they were stored until extraction and sample pretreatment.

\subsection{In vitro experiment - earthworms exposed to contaminated sawmill soil in the laboratory}

Earthworms (Eisenia fetida) were bred at $20^{\circ} \mathrm{C}$ in soil and peat in the laboratory and fed on dried horse manure. The earthworms were incubated in $500 \mathrm{~g}$ of two diverse soil samples in $900 \mathrm{ml}$ glass beakers. The soil samples were collected from sampling points 057 and 058 at the PA subarea at the sawmill site. The soils were homogenized by mixing and stored at room temperature at approximately $20^{\circ} \mathrm{C}$.

Twelve earthworms were collected from the breeding colony and were placed in each glass beaker. The earthworm pools corresponding to 057 and 058 were called W10 and W11. The beakers were wrapped with aluminum foil to prevent earthworms from escaping, but were 


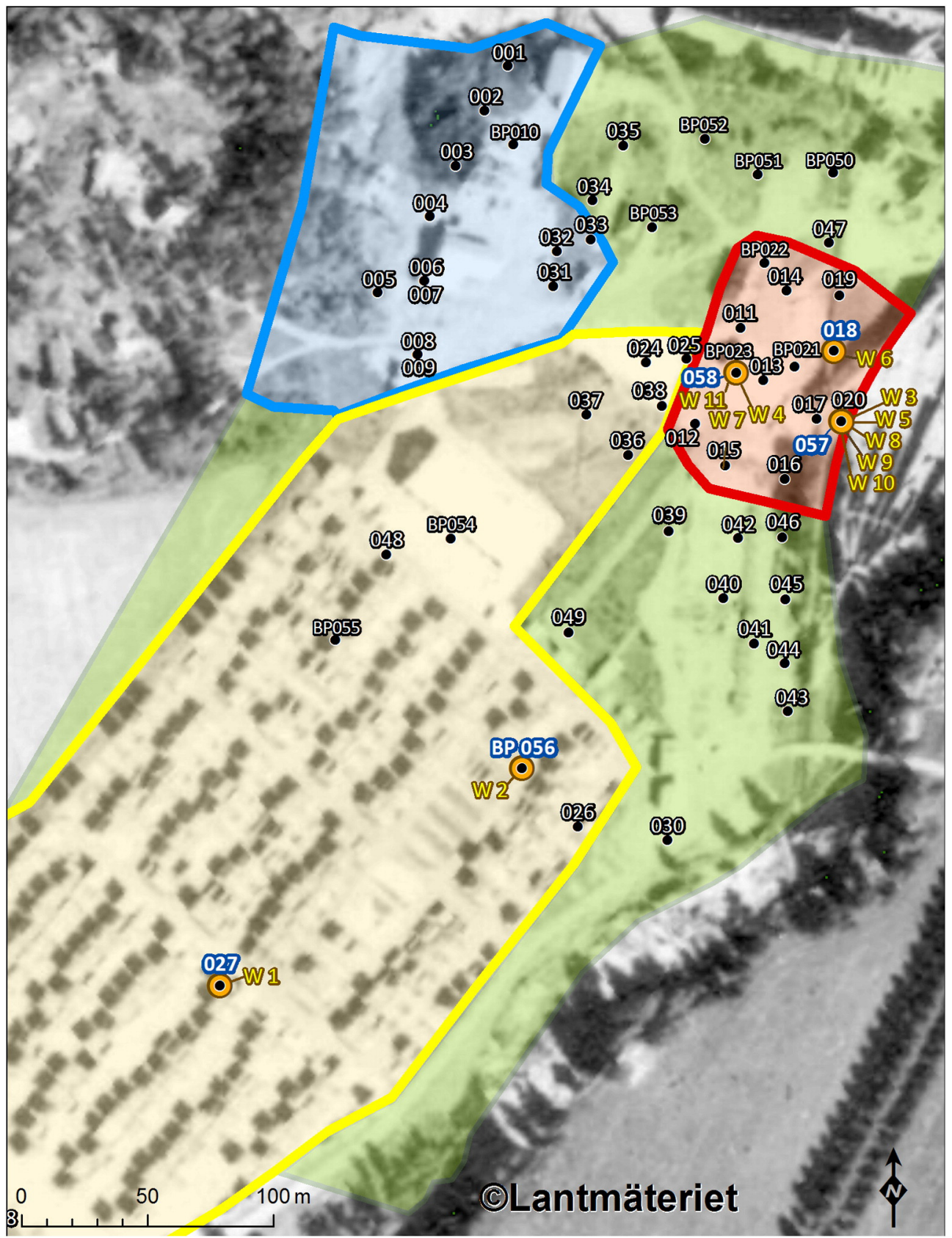

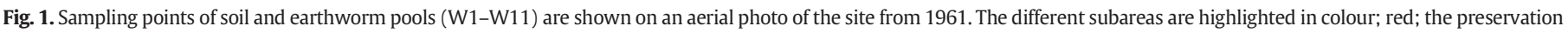

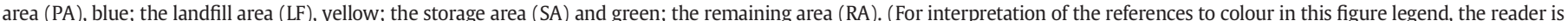
referred to the web version of this article.)

not kept completely dark. To provide suitable conditions for the earthworms, the soils field capacity was held at $60 \%$ moisture by maintaining a goal weight and adding water each day. The earthworms were exposed to the contaminated soils for 34 days. The exposure was ended by removing the earthworms and rinsing them in distilled water. After $48 \mathrm{~h}$ of gut purging as earlier described (Jager et al., 2005), the earthworms were weighed, transferred to a vessel with liquid nitrogen and thereafter transferred to a mortar.

\subsection{Cleanup and analysis of earthworms}

The earthworms were homogenized in a mortar with anhydrous sodium sulphate. For the in situ earthworms the weight ratio between earthworm and sodium sulphate was 1:5 and for the in vitro earthworms the ratio was 1:7 since these were damper. The homogenates were stored in a freezer $\left(-20^{\circ} \mathrm{C}\right)$ before sample extraction and analysis. The homogenates were extracted, using open column chromatography. First, the homogenates were spiked with ${ }^{13} \mathrm{C}$-labelled internal standard (EN 1948; Wellington Laboratories) before the lipid fractions were extracted by a mixture of $n$-hexane: dichloromethane (1:1). The lipid weights were determined gravimetrically. The extract was then treated using three different open columns (multilayer silica, AlOx and active carbon). The multilayer silica column contained $\mathrm{KOH}$ silica, neutral activated silica, $40 \% \mathrm{H}_{2} \mathrm{SO}_{4}$ silica gel, $20 \% \mathrm{H}_{2} \mathrm{SO}_{4}$ silica gel, neutral activated silica gel and $\mathrm{Na}_{2} \mathrm{SO}_{4}$ and was eluted with $n$-hexane. This column was followed by an AlOx column eluted with $n$-hexane/dichloromethane. Additional clean up and fractionation was done on an active carbon column, containing Carbopack C dispersed on Celite 545, which was 
eluted with $7 \mathrm{ml}$ of $n$-hexane for non-planar compounds and then $80 \mathrm{ml}$ of toluene to extract the planar fraction containing PCDD/Fs. Addition of ${ }^{13} \mathrm{C}$-labelled recovery standards was done prior to instrumental analysis. The extracts were kept in tetradecane.

Congener specific determinations of PCDD/Fs in the earthworms were performed by high resolution gas chromatography/high resolution mass spectrometry (HRGC/HRMS), Micromass Autospec Ultima operating at 10000 resolution using EI ionization at $35 \mathrm{eV}$. All measurements were done in the selective ion recording mode (SIR), monitoring the two most abundant ions of the molecular chlorine cluster. Chromatographic separation was achieved by splitless injection of $1 \mu \mathrm{l}$ of the extract on a non-polar DB-5MS column (J\&W Scientific; Folsom, CA, USA) using helium as the carrier gas. The DB-5MS column length was $30 \mathrm{~m}$, with an internal diameter of $250 \mu \mathrm{m}$ and nominal film thickness of $0.25 \mu \mathrm{m}$. When using a $30 \mathrm{~m}$ column co-elution of 2,3,7,8-substituted congeners with non-2,3,7,8-substitutes congeners may occur. In this study, a limited number of peaks were detected in the chromatograms and the retention times of most detected peaks corresponded well with that of their corresponding internal standards. From this knowledge we draw the conclusion that the presence of non-2,3,7,8-substituted congeners in the soil is overall limited and that it is mainly 2,3,7.8-substituted congeners detected. The limits of detection were calculated at an $\mathrm{S} / \mathrm{N}$ ratio of 3 and corrected for the recovery of the internal standard as a result of using isotope dilution methodology.

\subsection{GC/MS analysis and calculations}

Quantification of analytes in the extracts was performed using PC software, QuanLynx 4.1. The toxic equivalent quote (TEQ) were determined for all 2,3,7,8-substituded PCDD/Fs congeners based on $\mathrm{WHO}_{2005}$ toxic equivalence factors (TEF) (Van den Berg et al., 2006). When the sum for the total TEQ of the individual samples was determined, the concentrations of non-detected congeners, i.e., congeners below the limit of detection (LOD) were handled as the limit of detection divided by two (LOD/2).

\subsection{Quality assurance}

Recoveries of the labelled compounds ranged between 55 and $120 \%$. For positive identification of the detected native compounds, the two ions of the molecular cluster monitored simultaneously had to have an isotope ratio within $\pm 15 \%$ and the retention time had to be within \pm 1 s compared with the corresponding internal standard. An extraction blank was run with every batch of five samples. To ensure the quality of the analysis our laboratory participates yearly in different proficiency tests.

\subsection{Analysis of soil}

56 soil samples (001-BP056) were sampled at different times and analysed at two different accredited laboratories using an analytical method based on the United States Environmental Protection Agency (U.S. EPA) Method 1613 (EPA, 1994). The sampling and analysis of soil sample 001-053 has been reported in a former article (Henriksson et al., 2013). Soil samples BP054, BP055 and BP056 are pools from three different areas at the SA and were not included in the former article. The two soils from sampling points 057 and 058 were collected in the field at the sawmill site and taken back to the laboratory and used in the in vitro experiment, and analysed at the same time as the earthworms. Soxhlet extraction ( $24 \mathrm{~h}$ reflux in toluene) was applied to the samples, followed by the same clean up methodology that was applied to the earthworms.

\subsection{Bioaccumulation factor (BAF)}

$\mathrm{BAF}$, defined as the ratio between the PCDD/Fs concentration in earthworm and PCDD/Fs concentration in the soil was calculated as (Lyytikäinen et al., 2003):

$\mathrm{BAF}=\mathrm{C}_{W} / \mathrm{C}_{\mathrm{S}}$

where $C_{W}$ is the concentration in earthworm (pg/g f.w.) and $C_{S}$ is the soil concentration of PCDD/Fs (ng/kg d.w.). BAFs for the in vitro earthworms were calculated after 34 days of exposure.

\section{Results and discussion}

\section{1. $P C D D / F s$ concentrations in soil}

PCDD/Fs concentrations in soil collected from the site varied from below the detection limit to very high; $690,000 \mathrm{ng} \mathrm{TEQ}_{\mathrm{WHO}} \mathrm{mo05} / \mathrm{kg}$ d.w. (i.e., sample 018 representing the hot spot) and show the contamination distribution from the former processes at the sawmill (Henriksson et al., 2013).

The PCDD/Fs concentrations in the soil collected from the same sampling points as the collected earthworm samples (W1-W9) are listed in Table 1 . The great vertical and horizontal variation in contamination at the PA subarea is due to local spillage of Dowicide G. Furthermore, a fire at the site may also have affected the distribution of contaminants in a random manner (Henriksson et al., 2013). Soil 027 and BP056 were collected from the SA subarea, where the lowest PCDD/Fs concentrations at the site were encountered (0.62-35 ng TEQ ${ }_{W H O 2005} / \mathrm{kg}$ d.w.).

\section{2. $P C D D / F s$ concentrations in earthworms}

3.2.1. In situ experiment - earthworms collected from the sawmill site

PCDD/Fs concentrations in all pooled earthworm samples from the field are listed in Table 2, presented both in lipid weight (l.w.) and fresh weight (f.w.). The earthworms had an uptake of PCDD/Fs from the contaminated soil ranging from 290 to 520,000 pg/g f.w., showing a large spread of PCDD/Fs concentrations accumulated in the earthworms. The lowest PCDD/Fs concentrations (290 and 1200 pg/g f.w.)

Table 1

Concentrations of PCDD/Fs (ng/kg d.w.) in soil samples used in this study. Soil properties and the corresponding earthworm pools collected from the same sampling points as the soil are also presented in the table.

\begin{tabular}{|c|c|c|c|c|c|}
\hline Soil sample & 018 & 057 & 058 & 027 & ВР056 \\
\hline Subarea & PA & $\mathrm{PA}$ & PA & SA & SA \\
\hline Soil properties & $\begin{array}{l}\text { Sawdust } \\
\text { soil }\end{array}$ & Mouldy soil & $\begin{array}{l}\text { Mouldy } \\
\text { soil }\end{array}$ & $\begin{array}{l}\text { Gravel } \\
\text { sand }\end{array}$ & Sand \\
\hline $\begin{array}{l}\text { Earthworm } \\
\text { sample }\end{array}$ & W6 & $\begin{array}{l}\text { W3, W5, W8, } \\
\text { W9, W10 }\end{array}$ & $\begin{array}{l}\text { W4, W7, } \\
\text { W11 }\end{array}$ & W1 & W2 \\
\hline 2378-TCDF & 4300 & 74 & 120 & $<0.34$ & 0.25 \\
\hline 12378-PeCDF & 31,000 & 270 & 660 & 2.1 & 1.2 \\
\hline 23478-PeCDF & 41,000 & 910 & 1800 & 1.1 & 2.2 \\
\hline 123478-HxCDF & 390,000 & 1900 & 5600 & 9.5 & 6.6 \\
\hline 123678-HxCDF & 230,000 & 2100 & 4600 & 65 & 9 \\
\hline 234678-HxCDF & 220,000 & 5600 & 9500 & 15 & 12 \\
\hline 123789-HxCDF & 17,000 & 1300 & 3500 & 9.4 & 1.3 \\
\hline 1234678-HpCDF & $52,000,000$ & 210,000 & 800,000 & 510 & 340 \\
\hline 1234789-HpCDF & 240,000 & 2800 & 11,000 & 29 & 6.8 \\
\hline OCDF & 110,000000 & 220,000 & 240,000 & 220 & 130 \\
\hline 2378-TCDD & 710 & 41 & 37 & $<0.11$ & $<0.24$ \\
\hline 12378-PeCDD & 17,000 & 940 & 1000 & 3.7 & 3.7 \\
\hline 123478-HxCDD & 7800 & 2500 & 980 & 7.8 & 2.5 \\
\hline 123678-HxCDD & 83,000 & 15,000 & 19,000 & 62 & 26 \\
\hline 123789-HxCDD & 34,000 & 3300 & 4700 & 27 & 9.4 \\
\hline 1234678-HpCDD & 350,000 & 92,000 & 160,000 & 550 & 200 \\
\hline OCDD & 810,000 & 210,000 & 550,000 & 2300 & 660 \\
\hline Sum pg/g & $170,000,000$ & 770,000 & $1,800,000$ & 3800 & 1400 \\
\hline Sum pg TEQ/g & 690,000 & 7700 & 17,000 & 35 & 17 \\
\hline
\end{tabular}


Table 2

Concentrations of PCDD/Fs (pg/g f.w.) in earthworm pools.

\begin{tabular}{|c|c|c|c|c|c|c|c|c|c|c|c|}
\hline $\begin{array}{l}\text { Earthworm sampling } \\
\text { Subarea } \\
\text { Pooled soil }\end{array}$ & $\begin{array}{l}W 1 \\
\text { SA } \\
027\end{array}$ & $\begin{array}{l}\text { W2 } \\
\text { SA } \\
\text { BP056 }\end{array}$ & $\begin{array}{l}\text { W3 } \\
\text { PA } \\
057\end{array}$ & $\begin{array}{l}\text { W4 } \\
\text { PA } \\
058\end{array}$ & $\begin{array}{l}\text { W5 } \\
\text { PA } \\
057\end{array}$ & $\begin{array}{l}\text { W6 } \\
\text { PA } \\
018\end{array}$ & $\begin{array}{l}\text { W7 } \\
\text { PA } \\
058\end{array}$ & $\begin{array}{l}\text { W8 } \\
\text { PA } \\
057\end{array}$ & $\begin{array}{l}\text { W9 } \\
\text { PA } \\
057\end{array}$ & $\begin{array}{l}\text { W10 } \\
\text { PA } \\
057\end{array}$ & $\begin{array}{l}\text { W11 } \\
\text { PA } \\
058\end{array}$ \\
\hline 2378-TCDF & 0.22 & 0.60 & 8.9 & 22 & 0.35 & 28 & 3.6 & 7.0 & 10 & 3.8 & 2.4 \\
\hline 12378-PeCDF & 0.10 & 0.64 & 37 & 60 & $<1.7$ & 190 & 50 & 48 & 50 & 15 & 11 \\
\hline 23478-PeCDF & 0.25 & 1.7 & 95 & 180 & 1.6 & 390 & 210 & 150 & 130 & 31 & 22 \\
\hline 123478-HxCDF & 0.22 & 3.4 & 350 & 590 & 6.4 & 1600 & 410 & 260 & 220 & 44 & 56 \\
\hline 123678-HxCDF & 0.54 & 5.1 & 260 & 350 & 3.9 & 960 & 260 & 190 & 160 & 51 & 38 \\
\hline 234678-HxCDF & 0.63 & 3.7 & 540 & 530 & 13 & 1000 & 330 & 270 & 260 & 59 & 50 \\
\hline 123789-HxCDF & $<1.1$ & 0.85 & 130 & 310 & 0.97 & $<0.30$ & $<1.6$ & $<1.6$ & $<0.67$ & 16 & 18 \\
\hline 1234678-HpCDF & 32 & 170 & 11,000 & 13,000 & 580 & 210,000 & 19,000 & 13,000 & 18,000 & 1800 & 4100 \\
\hline 1234789-HpCDF & 0.48 & 2.2 & 260 & 190 & 7.5 & 850 & 190 & 83 & 68 & 34 & 66 \\
\hline OCDF & 72 & 430 & 22,000 & 36,000 & 990 & 300,000 & 12,000 & 8600 & 14,000 & 890 & 1200 \\
\hline 2378-TCDD & $<0.32$ & 0.11 & 5.5 & 6.7 & $<1.1$ & 8.2 & 3.4 & 9.4 & 8.2 & 4.7 & 1.4 \\
\hline 12378-PeCDD & 0.32 & 3.4 & 94 & 100 & 2.1 & 190 & 67 & 100 & 73 & 50 & 14 \\
\hline 123478-HxCDD & 0.35 & 2.4 & 170 & 25 & 3.0 & 77 & 51 & 110 & 100 & 38 & 7.2 \\
\hline 123678-HxCDD & 1.7 & 14 & 2200 & 360 & 32 & 970 & 880 & 1200 & 770 & 300 & 110 \\
\hline 123789-HxCDD & 0.35 & 2.6 & 240 & 78 & 2.6 & 210 & 90 & 160 & 95 & 43 & 11 \\
\hline 1234678-HpCDD & 16 & 58 & 12,000 & 710 & 240 & 1600 & 3300 & 5400 & 4300 & 690 & 420 \\
\hline OCDD & 170 & 500 & 26,000 & 3700 & 2600 & 4200 & 8500 & 12,000 & 8800 & 1100 & 1400 \\
\hline Sum pg/g (f.w.) & 290 & 1200 & 76,000 & 56,000 & 4500 & 520,000 & 45,000 & 42,000 & 46,000 & 5100 & 7400 \\
\hline Sum pg TEQ/g (f.w.) & 1.6 & 10 & 770 & 540 & 19 & 3000 & 570 & 580 & 510 & 150 & 98 \\
\hline Sum pg/g (l.w.) & 31,000 & 110,000 & $7,800,000$ & $5,100,000$ & 430,000 & $41,000,000$ & $3,800,000$ & $3,300,000$ & $3,700,000$ & $2,100,000$ & $2,600,000$ \\
\hline Sum pg TEQ/g (l.w.) & 170 & 890 & 80,000 & 49,000 & 1800 & 240,000 & 49,000 & 45,000 & 41,000 & 59,000 & 34,000 \\
\hline
\end{tabular}

were found in the earthworm pools from the SA subarea and the highest PCDD/Fs concentrations (4500-520,000 pg/g f.w.) were present in earthworm pools from the PA subarea. The earthworm sample collected at the hot spot, i.e., sampling point 018 , showed the highest $\mathrm{PCDD} / \mathrm{Fs}$ concentration (520,000 pg/g f.w.) of all analysed earthworm sample/ pools. To investigate the relationship between concentrations of 2,3,7,8-substituted PCDD/F congeners in earthworm pools, the logarithmic concentrations of all seventeen congener analysed in earthworm pools were plotted against the logarithmic concentrations of the corresponding congeners in the corresponding soil (Fig. 2). There was a strong correlation between the concentrations of individual congeners in soil and in earthworm pools. This is visualised in Fig. 2 where all samples related to sampling point 057 are plotted. The coefficient of determination, i.e. $\mathrm{R}^{2}$, varied between $0,69-0,99$ for all pools including the in vitro earthworm pools. The greater concentration of a congener in the soil, the greater concentration of the congener is detected in the corresponding earthworm pool.

There are a few publications reporting uptake of PCDD/Fs in earthworms from different locations. Nakamura et al. reported PCDD/Fs concentrations in earthworm collected from fallow rice fields in Japan (Nakamura et al., 2007). The concentration of PCDD/Fs and dioxin-like PCBs were 900,000 and 150,000 pg/g f.w. (670 and 150 pg TEQ/g l.w.)

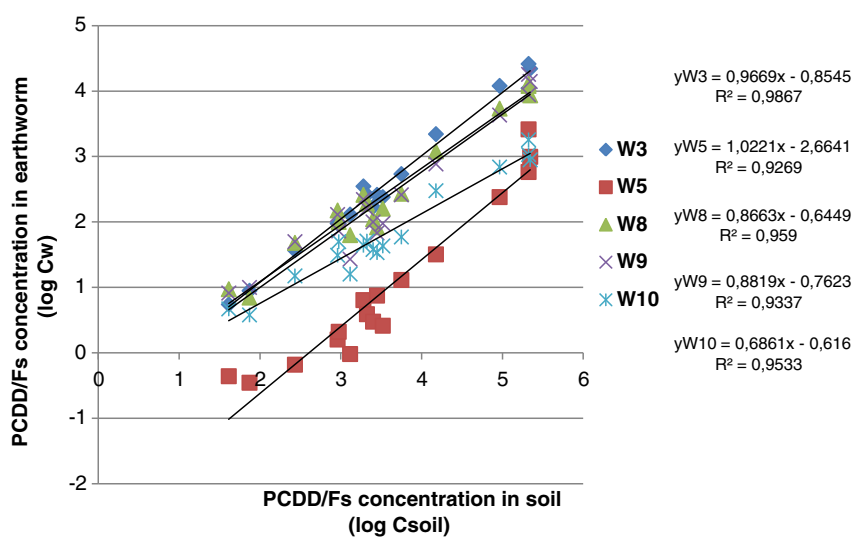

Fig. 2. Correlations of individual PCDD/F congener's concentration in soil and earthworms pools (W3, W5, W8, W9, and W10) sampled or bred in soil from sampling point 057. for earthworms from two different paddy fields. The corresponding concentration (PCDD/Fs and dl-PCBs) in the soils were 44,000 and $18,000 \mathrm{pg} / \mathrm{g}$ d.w. which are also much lower concentrations than reported in this study.

In another study by Shang et al. earthworms were collected from an E-waste dismantling area in China. In this study the earthworm concentrations ranged between 130 and $590 \mathrm{pg} / \mathrm{g}$ d.w. for PCDD/Fs (Shang et al., 2013). Based on the assumption that earthworms from this study had a water content of $80 \%$ (Dalby et al., 1996), the PCDD/Fs concentration in our earthworm pools range between 1500 and 15,000,000 pg/g d.w. The earthworm pool with the lowest concentrations in our study has ten times as high concentrations as the earthworm presented by Shang et al. However, the soils from the E-waste dismantling area in China, where the earthworms were collected, had PCDD/Fs concentrations ranging from 180 to $1170 \mathrm{pg} / \mathrm{g} \mathrm{d.w}$. which are ten to 100,000 times lower than the PCDD/Fs concentrations in the soil from Hillringsberg sawmill site.

Although the PCDD/Fs level in earthworm possibly reflect the degree of contamination where it dwells, our study show that earthworms collected from the same sampling point have different degree of uptake of PCDD/Fs. For example, four earthworm pools collected from the 057 sampling point varied greatly in PCDD/F concentration, from the highest PCDD/Fs level of $76,000 \mathrm{pg} / \mathrm{g}$ f.w. down to $4500 \mathrm{pg} / \mathrm{g}$ f.w., with a mean of $42,000 \mathrm{pg} / \mathrm{g}$ f.w. (standard deviation of $29,000 \mathrm{pg} / \mathrm{g}$ f.w.). The observed variations are probably a natural result of different earthworm species and differences in bioaccumulation between individuals. Factors that could affect uptake and bioaccumulation in earthworms are metabolism, behavior and the duration of exposure through the heterogeneity of the PCDD/Fs distribution in the soil, which varies greatly both horizontally and vertically (Lanno et al., 2004; Henriksson et al., 2013; Shang et al., 2013).

3.2.2. In vitro experiment - earthworms exposed to contaminated sawmill soil in the laboratory

Two colonies of earthworms, W10 and W11 were exposed to two different soils of different degree of dioxin contamination. No mortality was observed among the earthworms during the in vitro experiment. The accumulated concentrations of PCDD/Fs in the earthworms exposed to contaminated sawmill soil after 34 days in the laboratory were generally lower than the in situ earthworms, 5100 and 7400 pg/g f. w., respectively. The $\mathrm{PCDD} / \mathrm{Fs}$ concentrations are listed in Table 2 . The 
concentrations in the in vitro earthworms are about ten times lower than in the in situ earthworms. Reasons for this observation could be that Eisenia fetida used in the in vitro experiment differ in the uptake of PCDD/Fs compared to the species living at the site, or that the steady state for PCDD/F uptake might be slower at high concentrations of contaminants. Another explanation could be that the concentration of organic carbon was too low for the Eisenia fetida species and that the worms suffered from starvation which affected their uptake of contaminants (Spurgeon and Hopkin, 1999).

\subsection{Site specific uptake in earthworms}

All samples from the sawmill site are dominated by four PCDD/Fs congeners; OCDD, 1,2,3,4,6,7,8-HpCDD, OCDF and 1,2,3,4,6,7,8-HpCDF. The distribution of congeners in the earthworm pools is very similar to the distribution in the corresponding soil, both for in situ and in vitro exposed earthworms, reflecting their soil habitat. Overall the congener profile for PCDDs is similar between the soil and earthworm pools. However, the PCDF profile deviates a little between the earthworm pools and the profile in the soil. For example the earthworm pools W8 and W9 have higher concentrations of 1,2,3,4,6,7,8-HpCDF than OCDF meanwhile the soil sample 057 has higher concentrations of OCDF than 1,2,3,4,6,7,8-HpCDF (Tables 1 and 2). Possibly these variations are depending on differences in bioavailability. Other factors that can explain this variation are difference in species, a natural variation in the mobility of the earthworms, the spatial distribution of the contamination and the heterogeneity in the soil. Different species of earthworms have different capacities for uptake and bioaccumulation of PCDD/Fs based on their physiological and morphological characteristics, such as structure of their skin (Nannoni et al., 2011). They have also different behavior patterns, some of them have habitats in the top layer and other species accumulate compounds from deeper layers. The bioavailability in the soil varies over time depending on seasons and weather which changes the texture and composition of the soil which is controlled by physical and chemical properties, such as water content, oxygen content, salt content, $\mathrm{pH}$, clay content, mineral content and organic matter content. Also the biological property in the soil varies, such as microorganisms, algae, fungi, actinomycetes, nematodes, oligochaetes, insects, small mammals, plants trees etc. (Sijm et al., 2000).

The distribution of PCDD/Fs congeners in the in vitro earthworm pools have a tendency to correspond better to the soil than the in situ exposed pools, see percentage distribution of different congeners in Fig. 3. This is in line with the theory that the earthworms' mobility habitat in the wild life affects the PCDD/Fs uptake.

\subsection{Bioaccumulation of PCDD/Fs by earthworms}

Bioaccumulation factors (BAF) were calculated for each earthworm pool and showed that the BAF was higher in the earthworms collected in the soils with lower PCDD/Fs concentrations, see Tables 1 and 3. The highest BAF values were observed for the earthworm pools collected in the SA subarea where the PCDD/Fs contamination is lower than in the PA subarea. The lowest BAF for most congeners had the earthworm samples W5 and W6. W6 is collected at the "hot spot" at the sawmill site (sampling point 018) and the high soil concentration of contaminants seem to have a decreasing effect on the BAFs for all congeners analysed in the sample. This observation shows that high soil concentrations are not solely responsible for high concentrations in earthworm resulting from bioaccumulation. Thus; a low contaminated soil could yield earthworms with higher concentrations than a higher contaminated soil. Assuming that when assessing risks with PCDD/F contaminated soil, a combination of chemical analysis of soil PCDD/F concentrations and bioavailability should be employed.

Among the four earthworm pools collected at the 057 sampling point, W5 had significantly lower BAFs compared to the other three pools (W3, W8 and W9) which had higher BAFs in the same range.

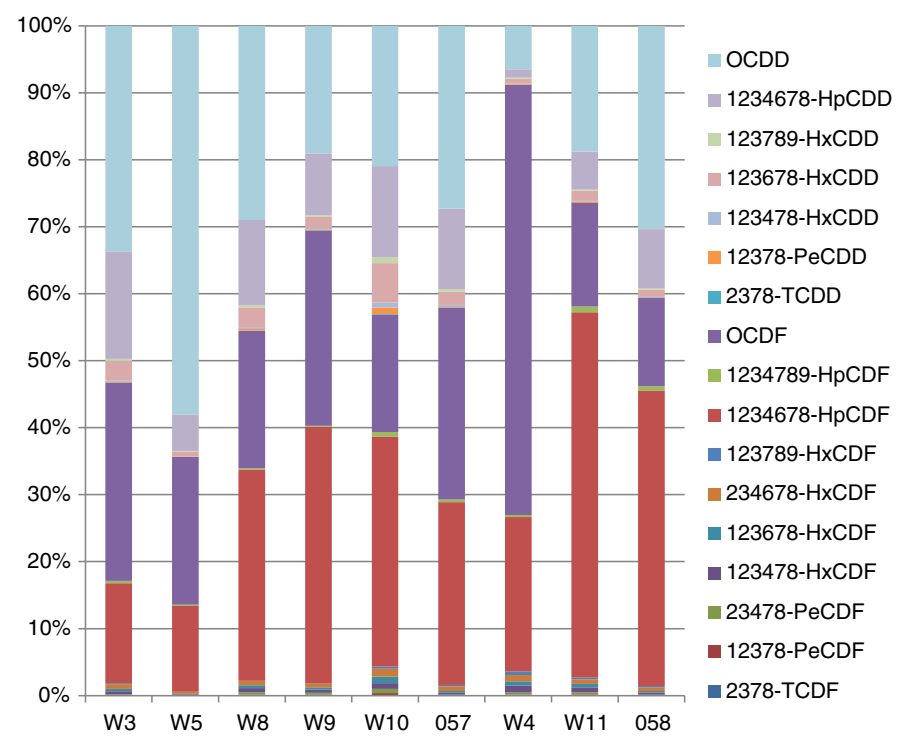

Fig. 3. Congener patterns are shown as percentage distribution in soil and earthworm pools collected from or bred in soil. Soil from sampling point 057 corresponds with earthworm pools (W3, W5, W8, W9 and W10) and soil from sampling point 058 corresponds with earthworm pools (W4 and W11).

W5 was the smallest earthworm pool and possibly it constitute of different species than the other earthworm pools. Expect for the W5, the in vitro earthworms showed lower BAF:s than the in situ earthworms collected from the same geographic sampling point as the soil used in the in vitro experiment. However, BAFs for individual congeners followed the same distribution in all earthworms exposed to the same soil. According to Shang et al. many studies suggest that a steady-state equilibrium of hydrophobic organic contaminants between soil and earthworm could be reach within 30 days (Shang et al., 2013). They also establish that it is difficult to determine the exposure time in the field environment since various factors could affect the bioaccumulation.

The earthworms show similar bioaccumulation for PCDD/Fs as the earthworms in the study of Shang et al. (Shang et al., 2013). Heptaand octa-homologues are generally less bioavaiable to earthworms than the lower chlorinated PCDD/Fs congeners. However, the trend wasn't distinguishable for PCDFs in pools W2, W3, W5 and W7. Smaller molecular size is considered to be an important factor affecting bioaccumulation. This correlates with other studies where the accumulation of 2,3,7,8-substituted tetra- and penta-chlorinated PCDD/Fs are generally two to three times higher than OCDD/F (Matscheko et al., 2002a, 2002b).

\section{Conclusions}

The overall conclusions is that PCDD/Fs are bioavailable to earthworms even when exposed to aged soil from former sawmill sites. The PCDD/Fs concentration in the soil correlates with the concentrations in the earthworms. However, high PCDD/Fs concentrations in soil are not solely responsible for high bioaccumulation in earthworms, since decreasing BAFs were observed with increasing soil contaminations. Thus, a less contaminated soil could yield higher concentrations in earthworms compared to a higher contaminated soil. The earthworms had the same congener pattern as found in the soil, indicating that the accumulation is not selective and no biotransformation occurs. The laboratory experiment (in vitro) indicates that the exposure time (34 days) might have been too short to reach steady state when using soil with high PCDD/Fs concentration since the in vitro earthworms had lower concentrations than the in situ earthworms. Another factor 
Table 3

BAFs for PCDD/Fs (pg/g f.w.) in earthworm pools.

\begin{tabular}{|c|c|c|c|c|c|c|c|c|c|c|c|}
\hline Earthworm pools & W1 & W2 & W3 & W5 & W8 & W9 & W10 & W4 & W7 & W11 & W6 \\
\hline Subarea & SA & SA & PA & PA & PA & PA & PA & PA & PA & PA & PA \\
\hline Corresponding soil samples & 027 & ВР056 & 057 & 057 & 057 & 057 & 057 & 058 & 058 & 058 & 018 \\
\hline 2378-TCDF & $<0.65$ & 2.4 & 0.12 & 0.0047 & 0.10 & 0.14 & 0.051 & 0.19 & 0.031 & 0.021 & 0.0064 \\
\hline 12378-PeCDF & 0.045 & 0.53 & 0.14 & $<0.0063$ & 0.18 & 0.19 & 0.057 & 0.091 & 0.076 & 0.017 & 0.0062 \\
\hline 23478-PeCDF & 0.23 & 0.79 & 0.10 & 0.0017 & 0.17 & 0.14 & 0.035 & 0.10 & 0.12 & 0.013 & 0.0095 \\
\hline 123478-HxCDF & 0.023 & 0.52 & 0.19 & 0.0034 & 0.14 & 0.11 & 0.023 & 0.11 & 0.073 & 0.0099 & 0.0040 \\
\hline 123678-HxCDF & 0.0083 & 0.57 & 0.13 & 0.0018 & 0.088 & 0.078 & 0.024 & 0.076 & 0.057 & 0.0083 & 0.0042 \\
\hline 234678-HxCDF & 0.042 & 0.31 & 0.10 & 0.0022 & 0.048 & 0.046 & 0.010 & 0.055 & 0.035 & 0.0052 & 0.0047 \\
\hline 123789-HxCDF & $<0.12$ & 0.65 & 0.10 & 0.00074 & $<0.027$ & $<0.00052$ & 0.012 & 0.089 & $<0.00046$ & 0.0052 & $<0.000018$ \\
\hline 1234678-HpCDF & 0.064 & 0.50 & 0.054 & 0.0027 & 0.063 & 0.084 & 0.0083 & 0.016 & 0.024 & 0.0051 & 0.0040 \\
\hline 1234789-HpCDF & 0.016 & 0.32 & 0.092 & 0.0027 & 0.030 & 0.024 & 0.012 & 0.018 & 0.017 & 0.0062 & 0.0035 \\
\hline OCDF & 0.33 & 3.3 & 0.10 & 0.0045 & 0.039 & 0.061 & 0.0040 & 0.15 & 0.048 & 0.0048 & 0.0028 \\
\hline 2378-TCDD & - & $<0.44$ & 0.13 & $<0.027$ & 0.23 & 0.20 & 0.12 & 0.18 & 0.091 & 0.037 & 0.012 \\
\hline 12378-PeCDD & 0.086 & 0.93 & 0.10 & 0.0022 & 0.11 & 0.078 & 0.054 & 0.10 & 0.066 & 0.014 & 0.011 \\
\hline 123478-HxCDD & 0.045 & 0.96 & 0.069 & 0.0012 & 0.046 & 0.041 & 0.015 & 0.025 & 0.052 & 0.0074 & 0.0099 \\
\hline 123678-HxCDD & 0.027 & 0.55 & 0.15 & 0.0021 & 0.081 & 0.051 & 0.020 & 0.019 & 0.045 & 0.0058 & 0.012 \\
\hline 123789-HxCDD & 0.013 & 0.28 & 0.073 & 0.00080 & 0.047 & 0.029 & 0.013 & 0.017 & 0.019 & 0.0022 & 0.0061 \\
\hline 1234678-HpCDD & 0.030 & 0.29 & 0.13 & 0.0026 & 0.058 & 0.046 & 0.0075 & 0.0045 & 0.021 & 0.0027 & 0.0044 \\
\hline OCDD & 0.073 & 0.75 & 0.12 & 0.012 & 0.058 & 0.042 & 0.0051 & 0.0066 & 0.016 & 0.0025 & 0.0052 \\
\hline
\end{tabular}

that might have influenced the results was that the exposed Eisenia fetida could suffer from starvation during the in vitro exposure experiments which affected their uptake of contaminants and reduced the bioaccumulation.

The result shows that PCDD/Fs pass from the terrestrial to biota and some concern regarding exposure risks from the studied sawmill site could be evoked. PCDD/F have a tendency to accumulate in living tissue and will pass through the food chain and reach higher concentrations in organisms at higher concentrations. Predators like mice and different kinds of birds feed on earthworms and can bioaccumulate PCDD/Fs and thereafter contribute to the spreading of these pollutants in the environment and in the food web when they become prey to other predators like owls.

This study show that risk assessment of PCDD/F contaminated soil based on total concentrations may not be conclusive. Spreading of pollutants via organisms should be considered for a more comprehensive risk analysis.

The use of the earthworm bioavailability model could be a useful tool to estimate the bioavailability and bioaccumulation of $\mathrm{PCDD} / \mathrm{Fs}$ contaminants in risk assessments of contaminated sites and assist in defining priority of sites with the most urgent need for remediation actions. When assessing risks with PCDD/Fs contaminated sites, a combination of chemical analysis of soil PCDD/Fs concentrations and bioavailability will improve risk assessment.

\section{Acknowledgements}

This study was supported and financed by Arvika municipality, Sweden, Department of Occupational and Environmental Medicine, Faculty of Medicine and Health, Örebro University, Sweden and MTM Research Centre, Örebro University, Sweden. We greatly acknowledge Helena Elgland and Ida Persson for their technical assistance.

\section{References}

Belfroid, A., Van den Berg, M., Seinen, W., Hermens, J., Van Gestel, K., 1995. Uptake, bioavailability and elimination of hydrophobic compounds in earthworms (Eisenia Andrei) in field-contaminated soil. Environ. Toxicol. Chem. 14 (4), 605-612.

Dalby, P.R., Baker, G.H., Smith, S.E., 1996. "Filter paper method" to remove soil from earthworm intestines and to standardise the water content of earthworm tissue. Soil Biol. Biochem. 28 (4-5), 685-687.

Emmerling, C., Strunk, H., 2012. Active dispersal of the endo-anecic earthworm Aporrectodea longa (Ude) in an experimental box. Soil Org. 84 (3), 491-498.

EPA, U. S., 1994. Method 1613: Tetra-through Octa-chlorinated Dioxins and Furans by Isotopic Dilution HRGC/HRMS.
Hagenmaier, H., Brunner, H., 1987. Isomerspecific analysis of pentachlorphenol and sodium pentachlorophenate for 2,3,7,8-substituted PCDD and PCDF at sub-PPB levels. Chemosphere 16 (8-9), 1759-1764.

Henriksson, S. Hagberg J. Bäckström, M. Persson, I Lindström, G, 2013. Assessment of PCDD/Fs levels in soil at a contaminated sawmill site in Sweden - A GIS and PCA approach to interpret the contamination pattern and distribution. Environ. Pollut. 180, $19-26$.

Jager, T., Van der Wal, L., Fleuren, R.H.L.J., Barendregt, A., Hermens, J.L.M., 2005. Bioaccumulation of organic chemicals in contaminated soils: evaluation of bioassays with earthworms. Environ. Sci. Technol. 39 (1), 293-298.

Kitunen, V.H., Valo, R.J. Salkinoja-Salonen, M.S., 1987. Contamination of soil around woodpreserving facilities by polychlorinated aromatic compounds. Environ. Sci. Technol. 21 (1), 96-101

Knuutinen, J., Palm, H., Hakala, H., Haimi, J., Huhta, V., Salminen, J., 1990. Polychlorinated phenols and their metabolites in soil and earthworms of sawmill environment. Chemposphere 20 (6), 609-623.

Laine, M., Jokela, J., Salkinoja-Salonen, M., 1995. Biomobility of organic halogen compounds from contaminated soil - earthworms as a tool. In: Munawar, M., Luotola, M. (Eds.), The Contaminants in the Nordic Ecosystem: The Dynamics, Processes and Fate, pp. 143-149.

Lanno, R., Wells, J., Conder, J., Bradham, K., Basta, N., 2004. The bioavailability of chemicals in soil for earthworms. Ecotoxicol. Environ. Saf. 57 (1), 39-47.

Länsstyrelsen Värmland, 2010. MIFO-database.

Lyytikäinen, M., Hirva, P., Minkkinen, P., Hämäläinen, H., Rantalainen, A.-L., Mikkelson, P., Paasivirta, J., Kukkonen, J.V.K., 2003. Bioavailability of sediment-associated PCDD/Fs and PCDEs: relative importance of contaminant and sediment characteristics and biological factors. Environ. Sci. Technol. 37 (17), 3926-3934.

Masunaga, S., Takasuga, T., Nakanishi, J., 2001. Dioxin and dioxin-like PCB impurities in some Japanese agrochemical formulations. Chemosphere (44), 873-885.

Matscheko, N., Lundstedt, S., Svensson, L., Harju, M., Tysklind, M., 2002a. Accumulation and elimination of 16 polycyclic aromatic compounds in the earthworm (Eisenia Fetida). Environ. Toxicol. Chem. 21 (8), 1724-1729.

Matscheko, N., Tysklind, M., de Wit, C., Bergek, S., Andersson, R., Sellström, U., 2002b. Application of sewage sludge to arable land-soil concentrations of polybrominated diphenyl ethers and polychlorinated dibenzo-p-dioxins, dibenzofurans, and biphenyls, and their accumulation in earthworms. Environ. Toxicol. Chem. 21 (12), $2515-2525$.

Nakamura, M., Yoshikawa, H., Tamada, M., Fujii, Y., Kaneko, N., Masunaga, S., 2007. Bioaccumulation of PCDD/DFS and dioxin-like PCBS in the soil food web of fallow rice fields in Japan. Organohalogen Compd. 69, 1452-1455.

Nannoni, F., Protano, G., Riccobono, F., 2011. Uptake and bioaccumulation of heavy elements by two earthworm species from a smelter contaminated area in northern Kosovo. Soil Biol. Biochem. 43 (12), 2359-2367.

OECD, 1984. Guidelines for Testing of Chemicals Earthworm Acute Toxicity Tests.

Persson, Y., Lundstedt, S., Öberg, L., Tysklind, M., 2007. Levels of chlorinated compounds (CPs, PCPPs, PCDEs, PCDFs and PCDDs) in soils at contaminated sawmill sites in Sweden. Chemosphere 66 (2), 234-242.

Rappe, C., Garå, A., 1978. Identification of Polychlorinated DibenzoFurans (PCDFs) in comercial chlorophenol formulations. Chemosphere (12), 981-991.

Reinecke, A.J., Nash, R.G., 1984. Toxicity of 2,3,7,8-TCDD and short-term bioaccumulation by earthworms (oligochaeta). Soil Biol. Biochem. 16 (1), 45-49.

SEPA/SNV, 2009. Riktvärden för förorenad mark, Modellbeskrivning och vägledning.

Shang, H., Wang, P., Wang, T., Wang, Y., Zhang, H., Fu, J., Ren, D., Chen, W., Zhang, Q., Jiang, G., 2013. Bioaccumulation of PCDD/Fs, PCBs and PBDEs by earthworms in field soils of an E-waste dismantling area in China. Environ. Int. 54, 50-58.

Sijm, D., Kraaij, R., Belfroid, A., 2000. Bioavailability in soil or sediment: exposure of different organisms and approaches to study it. Environ. Pollut. 108, 113-119. 
Spurgeon, D.J., Hopkin, S.P., 1999. Comparisons of metal accumulation and excretion kinetics in earthworms (Eisenia fetida) exposed to contaminated field and laboratory soils. Appl. Soil Ecol. 11, 227-243.

Van den Berg, M., Birnbaum, L.S., Denison, M., De Vito, M., Farland, W., Feeley, M., Fiedler, H., Hakansson, H., Hanberg, A., Haws, L., Rose, M., Safe, S., Schrenk, D., Tohyama, C.,
Tritscher, A., Tuomisto, J., Tysklind, M., Walker, N., Peterson, R.E, 2006. REVIEW the 2005 World Health Organization reevaluation of human and mammalian toxic equivalency factors for dioxins and dioxin-like compounds. Toxicol. Sci. 93 (2) 223-241. 